Ann. Génét. Sél. anim., I980, 12 (2), 209-2I3.

\title{
Note
}

\section{A case of subfertile cow with structural abnormalities of the X-chromosome}

\author{
H. HANADA and S. MURAMATSU \\ Department of Animal Breeding and Genetics, \\ National Institute of Animal Industry, \\ Tsukuba Norindanchi, P.O. Box 5, Ibaraki-ken PC 305 (Japan)
}

\section{Summary}

Cytogenetic examination was performed on a three years old Japanese Black, cow, which had been slaughtered due to subfertility. Structural chromosome abnormalities were found in $4 \mathrm{I}$ ( $20 \mathrm{p}$. IOo) out of 200 mitotic cells analysed.

The aberrations including deletions affected more specifically the X-chromosome. The frequency was significantly higher than that observed normally in cultures from a cow population of the same breed.

Cytogenetic studies of cattle with either sub- or infertility have recently appeared in the literature. In general, these animals showed a significantly high incidence of structural abnormalities of the autosome and /or the X-chromosome (HALNAN, I972; El-Nahass et al., I974; Bongso and BASRUR, I976). And, EL-NAHASS et al. (I976) found that the frequency of chromosome abnormalities was lower for A.I. bulls and breeding cows than for slaughter Cattle. Similar results were obtained in Swine population (Mrchelmann et al., I977). In the course of a chromosome survey of the Japanese Black Cattle, a case of low fertile cow with an unusually high frequency of structural abnormalities of the X-chromosome was detected.

The animal for which the chromosome examination was performed was a three years old Japanese Black cow, which had been culled owing to repeated abortions. Blood sample was taken from the femoral vein before slaughter, and cultured in vitro for $48 \mathrm{hrs}$ accordirg to the procedure described previously 
(Hanada and Muramatsu, I980). Two hundred well-spread metaphases were selected under the microscope and studied on microphotographs.

No phenotypic abnormalities were detected in the animal. The results of cytogenetic analysis are given in Table I. Most cells (79.5 p. I00) showed normal chromosome constitution without any structural abnormality. The rest (4I cells; 20.5 p. IOo) were abnormal cells with one or two structural abnormalities of the

TABLE I

Chromosome analysis in a subfertile cow

Analyse chromosomique chez une vache subfertile

No. of cells analysed . . . . . . . . . . . . . . . . . 200

Normal cells . . . . . . . . . . . . . . . . . . . . . . . 159 (79.5 p. гоo)

Cells with structural abnormalities . . . . . . . . . . . . . 4I (20.5 p. roo)

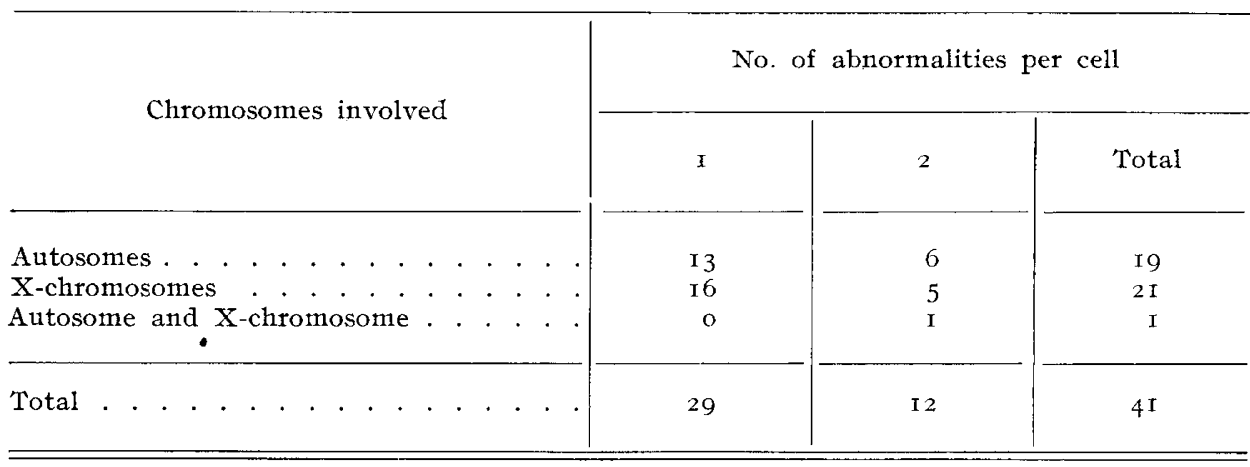

autosome and/or the $\mathrm{X}$-chromosome, but with a normal female complement, $2 n=60, \mathrm{XX}$.

The details of abnormalities are shown in Table 2 . The autosomal abnormalities were found in 20 cells (IO.0 p. IOO) involving 26 chromosomes, whereas those on the X-chromosomes were observed in 22 cells (II. p. roo) involving $27 \mathrm{X}$ chromosomes. The frequency and the nature of autosomal abnormalities were similar to those occurring spontaneously in cultures from a sow population of the same breed. On the other hand, the incidence of abnormalities of the X-chromosomes was about 6 times higher than that observed spontaneously. Furthermore, chromosome deletions, which were extremely rare in normal cattle, were observed with a high incidence $\left(\chi_{1}^{2}=47.9, P<0.00 I\right)$. In 5 cells, as shown in figure $I$, aberrations were recognized on both $\mathrm{X}$-chromosomes. In the present case subfertility in a cow was associated with a significant number of abnormalities of the X-chromosomes.

Similar results have been reported in a two years old infertile Black and White heifer (EI-NAHASS et al., I974) and a three months old Holstein calf affected with chronic tympanism of the rumen (GENEST and GuRy, I978).

On the other hand, autosomal abnormalities have also been detected in a high percentage of mitotic cells in cultures from sub- or infertile cattle (HALNAN, I972; 


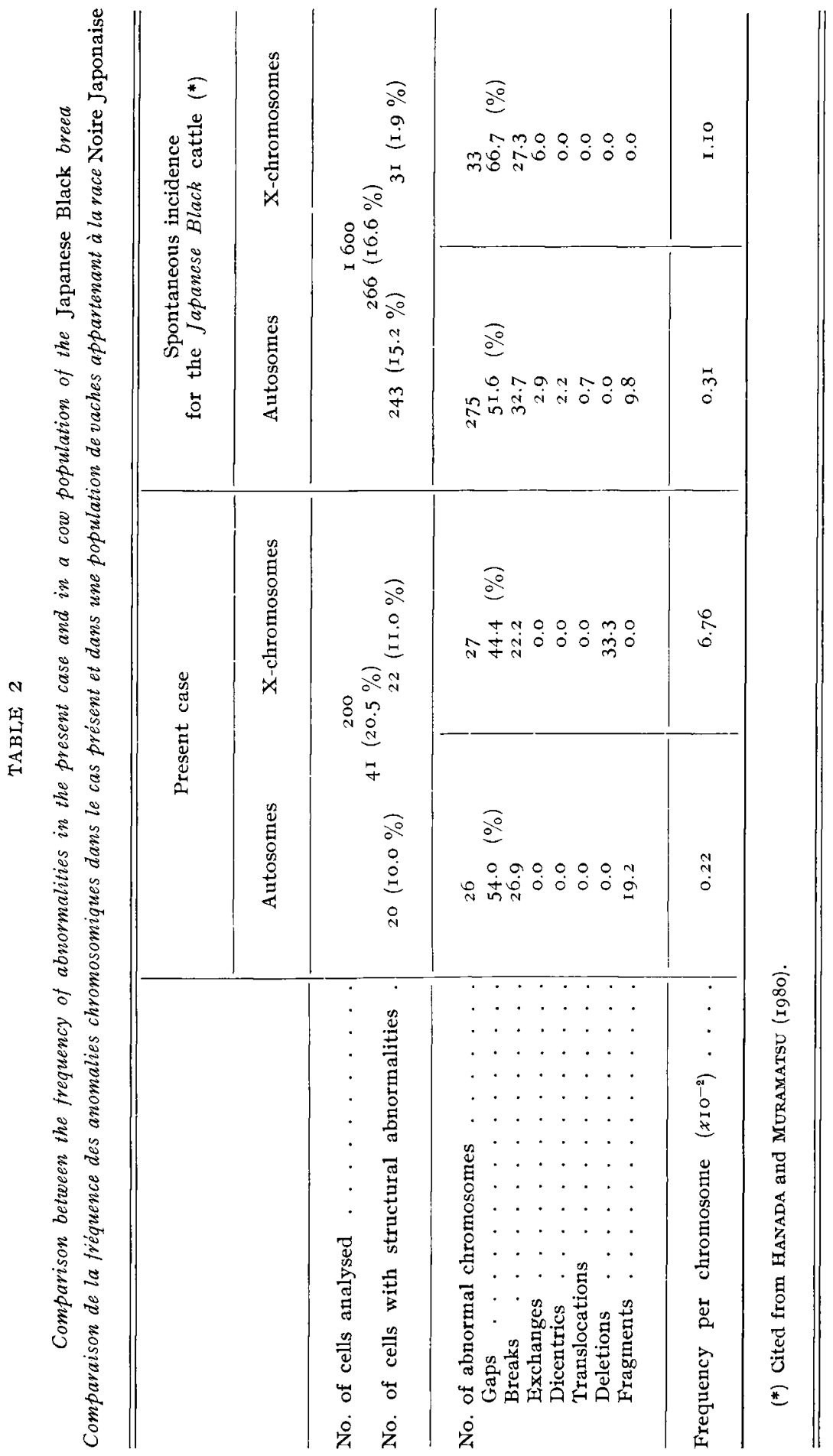




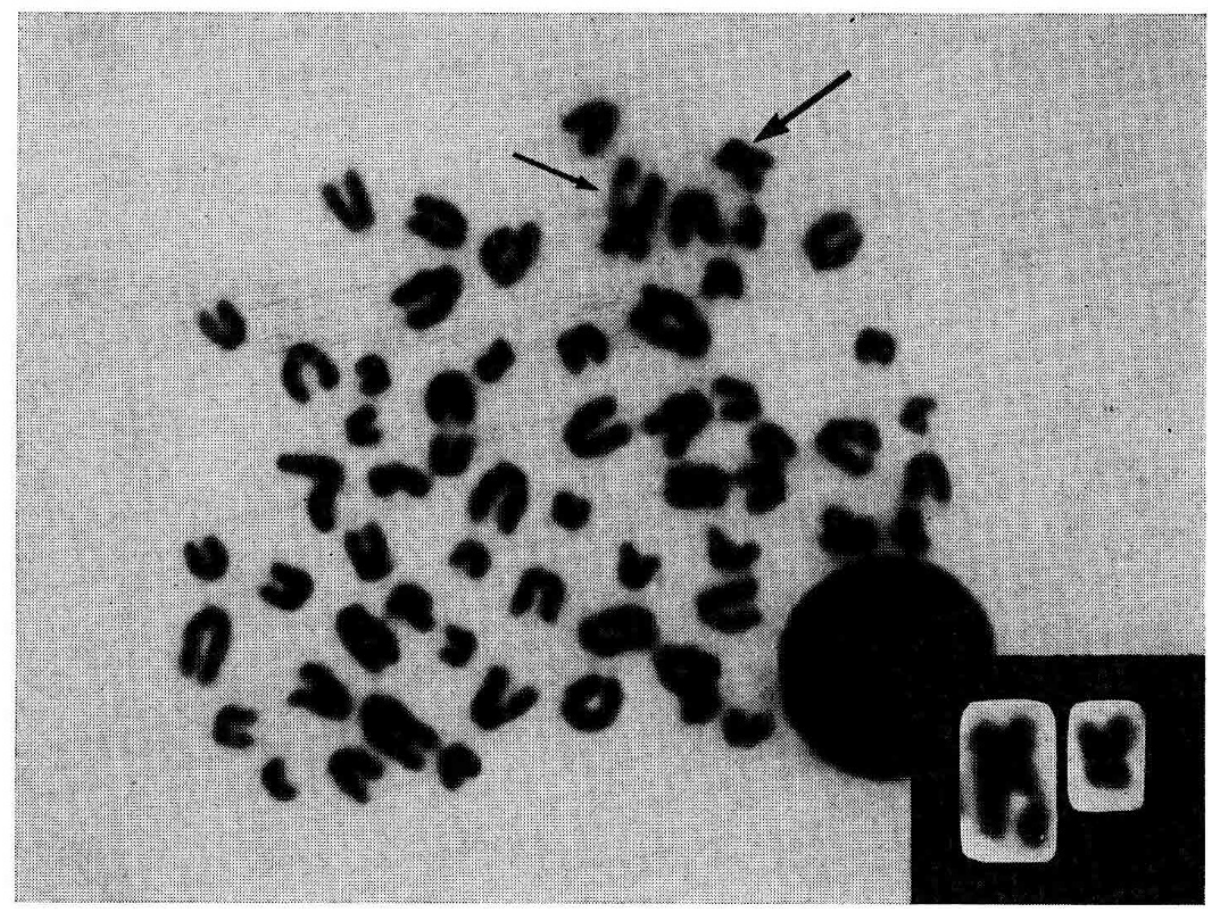

Frg. I. - Metaphase of a cell with a deletion (bold arrow) and a chromatid gap (light arrow) on both $X$-chromosomes.

Métaphase d'une cellule montrant une délétion chromosomique (flèche épaisse) et une interruption de la chromatide (flèche fine) affectant les deux chromosomes $X$.

Bongso and BASRUR, I976). These results suggest that there is a definite association between low fertility and a high incidence of structural abnormalities of the $\mathrm{X}$-chromosome and/or the autosome.

Received for publication in August I980.

\section{Résumé}

Subfertilité chez la vache accompagnée d'anomalies structurales $d u$ chromosome $X$

Une étude cytogénétique a été réalisée chez une vache subfertile appartenant à la race Noire Japonaise qui avait été abattue à l'âge de trois ans. Des anomalies chromosomiques structuraux ont été révélées dans $4 \mathrm{I}$ parmi les 200 cellules mitotiques comptées (20,5 p. IOO).

Les anomalies, y compris des délétions, affectaient plus particulièrement le chromosome $\mathbf{X}$. La fréquence des anomalies était statistiquement plus élevée que celle normalement observée chez les vaches de cette race. 


\section{Références}

Bongso A., BASRUR P. K., 1976. Chromosome anomalies in Canadian Guernsey bulls. Cornell Vet., 66, 476-488.

El-Nahass E., Syrjalia A., Mrchelmann H. W., Paurler S., I974. Mosaik einer X-Chromosomen-Aberration als wahrscheinliche Ursache der Sterilität bei einem Rind. Dtsch. tievärztl. $W \operatorname{sch} \gamma ., 81,397-398$.

El-Nahass E., Michelmann H. W., PaufleR S., i976. Chromosomale Untersuchungen von Zucht- und Schlachtrindern. Züchtungsk., 48, 264-277.

Genest P., GuAy P., r978. Structural abnormalities of the X-chromosome in a heifer. Canad. J. Comp. Med., 43, IIO-III.

Halnain C.R.E., r972. Autosomal deletion and infertility in cattle. Vet. Rec., 91, 572.

HALNAN C.R.E., I976. A cytogenetic survey of IIOI Australian cattle of 25 different breeds. Ann. Génét. Sél. anim., 8, I3I-I39.

HANADA H., MURAmatsu S., I980. Spontaneous chromosome aberration rate in the peripheral lymphocytes of the Japanese Black Cattle (to be submitted).

Michelmann H. W., Eil-Nahass E. M., Paufler S., i977. Vergleichende Chromosomenuntersuchung bei Zucht- und Mastschweinen mit Hilfe der Giemsa-Färbung und der Bänderungstechnik. Züchtungsk., 49, 294-300. 